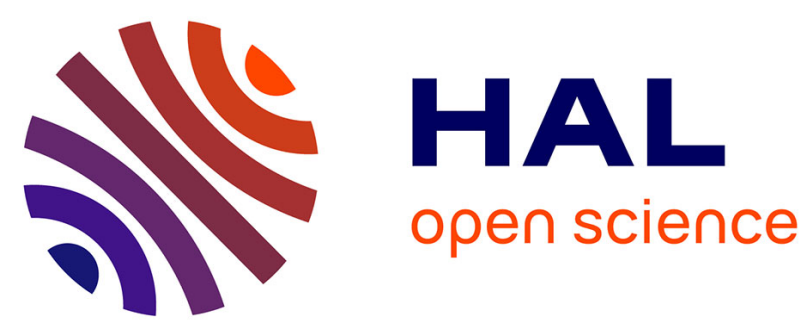

\title{
"Let Go of Your Ball, This Is Not the NBA!": The Influence of Hip-Hop Ball on Institutional Basketball Around Paris (France): Cultural Antagonisms and Difficult Cohabitation
}

David Sudre, Hélène Joncheray, Antoine Lech

\section{To cite this version:}

David Sudre, Hélène Joncheray, Antoine Lech. "Let Go of Your Ball, This Is Not the NBA!": The Influence of Hip-Hop Ball on Institutional Basketball Around Paris (France): Cultural Antagonisms and Difficult Cohabitation. Journal of Sport and Social Issues, 2019, 43 (3), pp.147-166. 10.1177/0193723519832464 . hal-02957185

\section{HAL Id: hal-02957185 \\ https://hal.science/hal-02957185}

Submitted on 21 Oct 2020

HAL is a multi-disciplinary open access archive for the deposit and dissemination of scientific research documents, whether they are published or not. The documents may come from teaching and research institutions in France or abroad, or from public or private research centers.
L'archive ouverte pluridisciplinaire HAL, est destinée au dépôt et à la diffusion de documents scientifiques de niveau recherche, publiés ou non, émanant des établissements d'enseignement et de recherche français ou étrangers, des laboratoires publics ou privés. 


\title{
"Let Go of Your Ball, This Is Not the NBA!": The Influence of Hip-Hop Ball on Institutional Basketball Around Paris (France): Cultural Antagonisms and Difficult Cohabitation
}

\author{
David Sudre, Helene Joncheray, and Antoine Lech
}

\begin{abstract}
The nature of the game of basketball, which is to score more hoops than the opposing team while respecting a set of rules, has often been questionned. Young players have been developing new ways to play and think basketball ever since the advent of the American hip-hop basketball ("hiphop ball") culture in France in the noughties. However, this way of playing basketball is viewed negatively by club coaches, who are the guardians of institutional basketball. Through participant observation and the interviewing of five coaches and 32 players, this article seeks to measure the consequences of what may be seen as a cultural divide. Our findings show how coaches depreciate hip-hop ball culture and sometimes stigmatize players to reinforce their own legitimacy within institutional basketball. Also, our data illustrate the players' ability to shift from one basketball culture to the next in an attempt to gain recognition in institutional basketball.
\end{abstract}

\section{Keywords}

basketball, hip-hop ball, culture, deviance, qualitative research

David Sudre : Univ. Littoral Côte d'Opale, ULR 4477 - TVES - Territoires Villes Environnement \& Société, F-59140 Dunkerque, France

Helene Joncheray : French Institute of Sport (INSEP), Laboratory Sport, Expertise and Performance (EA 7370) \& Institut des Sciences du Sport Santé Paris (EA 3625),

Antoine Lech : Paris Descartes University, France 3Institut des Sciences du Sport Santé Paris (EA 3625), Paris Descartes University, France 


\section{Introduction}

As a basketball reference, the North American professional basketball champion- shipNational Basketball Association (NBA) - has a major influence on young French basketball players (Archambault, Artiaga, \& Bosc, 2007). This craze for American basketball harks back to Michael Jordan's rise to stardom and the Olympic domination of the American basketball team, nicknamed the "Dream Team," in the 1990s. The Dream Team brought together the best players from the NBA, such as Michael Jordan and Magic Johnson, for the 1992 Olympic Games in Barcelona. Also, the success of several French players in the NBA has been a major factor in changing the ways young French players conceive and play basketball. French passion for American basketball originated in 1984 with the rise of "Canal+," a leading French TV channel. Canal+ was the first French channel to broadcast NBA basketball games extensively in France (Bolotny, 2002). To a large extent, powerful mainstream media, especially TV networks, within a favorable cultural globalization context (Andrews, 1999; Appadurai, 1996; Fortunato, 2000; Giulianotti \& Robertson, 2007) contributed to making NBA basketball "the" dominant model for a very large number of young French players (Archambault \& Artiaga, 2007). In addition, NBA basketball-related newspapers (Rebillard, 2002), by following the advent of the streetball phenomenon, known as the "AND1" movement, which was very popular in the United States in the late 1990s, contributed to reinforce this craze for the American model. AND1 clothing brands organized important street basketball tournaments to promote their products all across the United States. These brands even produced video cassettes (called "AND1 mixtapes"), mixing footages from street matches with hip-hop music in the back- ground. These mixtapes turned streetballers like Skip To My Lou, Hot Sauce, or The Professor into celebrities (Palmer, 2004). In the language specific to basketball, AND1 means scoring a basket and getting fouled. The field goal is valid, and the scorer gets a bonus free throw that gives him the possibility of scoring an extra point. In the wake of the NBA and AND1 movement, many French basketball players started to call themselves "Cain-ris"- a French neologism and a backslang word for "Ri-cain," a diminutive of "Américain" (American). Aged 14 to 20 years, these French basketball players identify strongly with Afro-American basketball and hip-hop stars. The osmo- sis between the hip-hop culture and basketball has a name: "hip-hop ball” (Boyd, 2003). Hip-hop ball stars' game codes, dress codes, and attitudes have been taken up by Cain-ris and adapted to their own sociocultural environment (Sudre, 2014).

It is important to note, however, that the hip-hop ball culture does not fully extend to French institutional entities, namely basketball clubs affiliated to the French Basketball Federation (Fédération Française de Basket-ball, FFBB). The influence of hip-hop culture, which changed the players' relationship to basketball and their way of playing the game, is felt differently by club coaches. Indeed, hip-hop ball culture is often frowned upon and rejected by coaches, insofar as it endangers, in their view, the institutional and collective basketball good practices that they wish to pass on to their players. Hip-hop culture in French basketball has not reached the same racial and political status as in the NBA (Colas, 2015, 2016; Lane, 2007; 
Lorenz \& Murray, 2014) and is still widely unpopular among the guardians of institutional basketball in France (Andrews, 2007).

As a result, the integration of Cain-ris in FFBB-affiliated clubs now poses a prob- lem for coaches. It is therefore necessary to analyze the often conflicting relationships between the coaches, who promote the institutional model, and the Cain-ris, who are fascinated by the American hip-hop ball culture. The challenge is to measure the con- sequences of this conflict, which raises two fundamental questions:

-• Research Question 1: Does the deprecating of hip-hop ball culture reinforce the legitimacy of baskeball coaches and thereby maintain their dominant posi- tion on the French basketball scene?

•- Research Question 2: How do Cain-ri players fit in institutional basketball, and how do they cope with their coaches' injunctions?

To answer these questions, it is essential to first define the sociological characteris- tics of coaches and Cain-ris and look into the influence of hip-hop ball on the Cain-ris' ways of

playing. Second, the "labeling process" (Becker, 1963) of Cain-ris as "devi- ant" players by their coaches must be questionned. In particular, the consequences of this labeling for both the coaches and the Cain-ris must be analyzed. Finally, the Cain- ris' ability to adjust to institutional basketball and shift from one ball culture to another (Bastide, 1955), in an attempt to gain recognition, will be addressed.

\section{The Hip-Hop Ball Culture}

The tension between players and coaches over the hip-hop ball issue is nothing new in French basketball. There has always been a gap between the prerogatives of individual playerswho have been willing to "transform the spatiotemporal experiences of modernity by inventing artistic 'varieties of basketball modernism"' (Colas, 2015, p. 268) - and the coaches' competitive and moral values (Colas, 2015). In the United States, in particular, the hip-hop ball culture is often associated with popular myths and centers, for historical reasons, on race (Colas, 2016). In France, NBA basketball is the main ambassador of American basketball. Unquestionably, its exposure on screens and in newspapers in France is huge (Bolotny, 2002; Monier \& Vivier, 2012). Yet, the practice of basketball in the United States is quite heterogeneous. The playing styles observed in various American states, such as Indiana, or in big City streets (as in New York's Rucker Park's courts, for instance) are different from NBA playing styles (Descamps \& Vacheron, 2013). The same may be said about the National Collegiate Athletic Association (NCAA) basketball, which differs in many ways from NBA basketball. To symplify, NBA rules and playing styles are similar to European basketball and the Euroleague. Indeed, collective benefit pre- vails (generally) over individual achievements (Archambault, 2012; Khomutovaa, 
2016). However, other basketball practices, characterized by a more spectacular style, put a stronger emphasis on individual skills (Andrews, 2007; Descamps \& Vacheron, 2013).

Given this heterogeneity of playing styles and the geographic diversity of basket- ball institutions, it is essential to exercise caution before attempting to interpret the influence of hiphop ball over French basketball players. For the sake of accuracy, hip-hop ball, as a sporting and cultural phenomenon and as a reference game, must be defined. A proper definition is needed to better understand the so-called hip-hop "inva- sion" of the NBA (Boyd, 2003) and the rise of streetball in the United States in the early noughties.

We therefore define hip-hop ball as the combination of basketball with hip-hop, two cultural practices involving young Afro-Americans from popular backgrounds.

The hip-hop ball movement, which combines unique dressing styles with specific musical tastes, was put in the spotlight by NBA stars (Allen Iverson, Carmelo Anthony) and AND1 streetballers (Skip To My Loo, Hot Sauce). These players wear outfits that are specific to this universe, and some of them are also amateur or even professional rappers on their free time. Unquestionably, the hip-hop movement has left its mark on the playing styles of American basketball that currently make the headlines (Boyd, 2003).

In America's poorer urban areas, residents are heavily engaged in hip-hop (Frey, 2004; Riess, 1991), as well as in basketball, called "The City Game" (Axthelm, 1970). These two practices do not require players to have a lot of money or equipment (Andrews, 2007); hip-hop and basketball seem to offer upward mobility opportunities to African Americans (Boyd, 2003). Additionnally, hip-hop and basketball are tools for protest, social struggle, and political struggle that are used by African Americans as a : "social space of cultural creativity and symbolic recognition, of political resistance and of civic reclamation for part of the black community .... Sport was, inside a society structured by racism, an institution central to the battle of AfricanAmericans for equal civic rights". (Martin-Breteau, 2011, p. 1)

It is worth remembering, however, that basketball was not initially created by, and for, African Americans, contrary to general belief (Colas, 2016; Harter, 2007), but also that some Black NBA players have suffered from clichés associating them to criminals or gang members (Cole \& Andrews, 1996; Cunningham, 2009; Ferber, 2007; Lane, 2007; Leonard, 2006, 2010).

Among young French players, the practice of basketball is clearly linked to hip-hop ball culture (Monier \& Vivier, 2012; Sudre, 2012), much to the discontent of the bas- ketball establishment (in this case, the FFBB). Indeed, while conducting our survey, nearly all of the young interviewees answered "hip-hop" to the question: "which style of music do you associate to basketball the most"? As hip-hop ball has become a refer- ence culture in basketball around Paris, it has changed the game, and this influence may be felt among not only streetballers but also club basketball players. In turn, this social phenomenon has led to a process of acculturation (Lakey, 2003). In actual facts, both on and off the courts, many young people replicate not only the hip-hop ball stars' ways of behaving, dressing but also, and more importantly, playing (Sudre, 2014). 


\section{Coaches and Cain-ris}

Our survey was carried out within the club of a popular city (French National Institute for Statistics and Economic Research, INSEE, survey, 2012), called Champigny and located in the south-east of Paris. The club has about 250 basketball license holders. Our field work was initiated in this club because one of the researchers had already been involved in this study for more than 10 years, which made it possible for us to use "participant observation" (Abercrombie, Hill, \& Turner, 2000; Platt, 1983; Soulé, 2007). Moreover, this researcher has also been a coach and a player in that club since 1998. One of the benefits of his position was to generate a relationship of trust with the young club members, giving him the opportunity to observe them during trainings and matches. Participant observation allowed to understand their behavior and the things they said in situ. Nevertheless, by staying on the Champigny courts, our research team feared that they would lack critical distance and would not be able to measure the relationships between the coaches and the Cain-ri players in a fair way. Therefore, for 3 consecutive years, we conducted observational studies at three other basketball clubs in the east side of Paris and participated in five basketball camps organized in Paris during the school holidays.

While conducting this survey, our primary focus was on two groups - the coaches and Cain-ris - with a view to find out how they mingled, interacted in a common space (the basketball court) and shared a common passion (i.e., basketball). In addition to observing them, we conducted long interviews with five coaches and 32 Cain-ri play- ers. In the interview excerpts quoted in this article, the interviewees' first names were changed to preserve their anonymity.

Three of the five coaches trained at the Champigny club and had similar sports and social trajectories. Marie-Thérèse (a 65-year-old coach) was a high-level athlete and a member of the French national basketball student team. She is now a retired Physical Education and Sport (PES) teacher, married to a PES teacher. Marie-Thérèse also has a Level 1 teaching certificate, known as Brevet d'État d'Éducateur Sportif (BEES). The BEES is a national sports instructor's certificate that recognizes teaching, managing, or expertise skills in a sport. This diploma is delivered by the Ministry of Sports. The FFBB requires coaches who aspire to train high-level teams to obtain this diploma. Marie-Thérèse has been running the Champigny basketball club for more than 30 years. Another coach, Caroline (a 48-year-old), is also a PES teacher married to a PES teacher. She played at a national level, holds a Level 2 BEES and is the club's technical director. Guillaume (a 35-year-old) played in Espoir Pro B, which equates to the NCAA's second division. It is a basketball championship that mainly aims at developing professional players. Guillaume has a regional coaching diploma ("diplôme d'entraîneur régional") as well as a bachelor's degree in Sports Sciences. The other two coaches are from two different clubs and also have an institutional basketball background. Jean-Philippe (a 31-year-old) holds a Level 1 BEES and works for his club full time. Nicolas (a 36-year- old), who teaches at a kindergarten, plays basketball at a regional level and has a regional coaching diploma. It is important to highlight that unlike most Cain-ris, these five coaches are White and have a middle-class background. 
These coaches run teams of players aged 15 to 20 years. On average, four or five players out of the 15 players supervised by these coaches define themselves as Cain- ris. Cain-ris $(n=$ 32) - our main focus for this survey - generally come from popular classes or belong to the lower middle classes (Siblot, Cartier, Coutant, Masclet, \& Renahy, 2015). Their parents are predominantly employed as nurses, post office tell- ers, childminders, couriers, or bank clerks. There is one social characteristic common to the Cain-ris: the place where they live. More than two-thirds of the interviewees reside in the south-east of Paris's popular neighborhoods, such as "Bois 1'Abbé" and "Les Mordacs" in Champigny or "Cité Balzac" in Vitry. About 10 of these players live with their mothers. Most of them are high school or college students, enrolled in short technical trainings. Additionnally, most of them have roots in the Caribbean and/or in subSaharan Africa. We should point out that the Cain-ris' relation to skin color or "melanic pride" (Ndiaye, 2008) allows for a better understanding of their identifica- tion to hip-hop ball protagonists. The melanic aspect, in particular, reinforces their passion for the Afro-American culture. Indeed, racialized identification is there (Colas, 2016) and can be felt through the Cainris' infatuation for the Afro-American basket- ball, that is for the Black world shining on the basketball and media scenes (Gilroy, 1993; Lapchick, 2008; Martin-Breteau, 2011). For young basketball players in the Paris area, hip-hop ball seems to be a rewarding diasporic reference through which they positively redefine themselves, even reverse the stigma associated to their skin color, and they take pride in this achievement (Hebdidge, 1979; Wieviorka, 2001). The skin color issue has thus an important part to play in the Cain-ris' identification pro- cess. However, the racial issue does not seem to have any real impact on the way coaches perceive Cain-ris. Unlike some respected Black players in the NBA (Lorenz \& Murray, 2014), Cain-ris are not respected or disrespected because of the color of their skin but on the grounds of their love for the hip-hop ball culture. We should also mention that the survey targeted a young public who identify themselves as hip-hop ball players.

\section{The Influence of Hip-Hop Ball on Playing Styles}

Some young players from the Paris area envision the game differently, and this has led them to push back the notion of the "collective" (Sudre \& Oboeuf, 2015). Our observa- tions have led us to believe that young Cain-ris increasingly value individual accom- plishment with the aim of achieving "social one-upmanship" (Colas, 2016). For them, performing a whole range of moves (dribbles, dunks, blocks) and being able to repro- duce them during matches has become as crucial as scoring a field goal or helping their team to win (Champigny diary entry excerpt). Court vision, perfectly timed passes, floating in defense to better help their teammates, and so on, all these techniques related to team play are in fact often less valued by Cain-ris. Increasingly, putting themselves in the spotlight during a match has become a much more important goal for them.

As for the Cain-ris' playing style, one of the ways of achieving social one-upman- ship has been to perform remarkable technical feats during games. By resorting heav- ily to dribbling, 
the player becomes the focus of the game and takes this opportunity to show the audienceunderstood here as the other players on the court as well as the spectators - all of their technical know-how (Champigny diary entry excerpt). Different types of dribbles, called "tricks," are borrowed from hip-hop ball stars: cross-overs (cross dribbles performed at full speed by passing the ball through their legs or behind their back for example); magic tricks where the ball disappears in the XXL shirt; or even dribbles performed close to the ground by rolling over while keep- ing the ball under control. All of these moves observed during NBA matches or on AND1 mixtapes have been learned and reproduced. The words of Malik (a 17-year- old), who plays for Champigny-sur-Marne, reflect the process of change which has happened in some players' playing style: "One day, I went and buy myself a pair of sneakers at Foot Locker. They gave me a tape and I was traumatized, really traumatized! To explain to you to what extent, I watched the tape then, it was a long time ago [he laughs], I was small, we took a basketball and went to play in the back. There was no hoop, we just dribbled, we tried to copy. We were small but when we saw that, we were like wow! What is that?!"

Beyond a way to move around the court, dribbling, which "was originally prohib- ited in basketball" (Colas, 2015, p. 274), has become a form of expression that allows to assert one's individual playing skills and thus be recognized by one's peers (Sudre \& Oboeuf, 2015). Even though, as Colas (2015) wrote, "dribbling is not antithetical to passing and its cooperative values, but rather complements them" (p. 275), it is still seen, by coaches, as an assertion of the priority of the individual over the collective (Colas, 2015, p. 275).

Dunks are another individual feat a lot of young players try to accomplish. Those who achieve it are then continually applauded by their peers and loudly cheered during the match. Dunks are remembered and, assuredly, the players talk about them at the end of the game (Paris basketball camp diary entry excerpt). Yet dunks, as well as some ways of dribbling, are not to the coaches' liking. This was already the case in NBA in the 1950s, where dunking "came to be seen as a gratuitous and ostentatious exhibition of narcissism, revealing a dangerous disregard and disrespect for the game itself, including its moral values" (Colas, 2016).

Assists can also be a good way to put oneself forward. It may come as a surprise, but if the assist is a symbol of the collective game, it can nevertheless take on an indi- vidual dimension in the Cain-ris' logic of the game. The harder and/or the more aes- theticized the assist (behindthe-back, between the legs, "no-look pass" or even "laser pass," in which the ball is sent at great speed), the better for the player in terms of recognition (Champigny diary entry excerpt). Assists, thus redefined in the hip-hop ball culture, become an opportunity to "shine," especially if the player succeeds in delivering an incredible assist to a teammate. Behind a purely collective skill, there also lies a real desire to showcase oneself.

In defense, the player can also find a way to enhance himself individually by trying to defend spectacularly. Blocks will also allow him to display his individual talent to his teammates. For young players influenced by the hip-hop ball culture, the foundations of one-on-one defense and collective defense will take a back seat. For instance, they do not feel concerned by the defensive footwork, whose aim is to con- tain the opposing player and never to be taken out of 
play. On the contrary, they will have a tendency to be overrun more or less intentionally or not to "defend using solid legs" to have a better chance at blocking their opponents' shots (Paris basketball camp diary entry excerpt). Sometimes, the defender lets the attacking player shoot to have a chance to block his shot. From a collective standpoint, the risks of conceding a field goal increase but on an individual level, it is a possibility of stepping up to the plate. Defensive values are upset, and only the spectacular becomes an indigenous evalua- tion criterion of performances, in contrast to institutional criteria (Sudre \& Oboeuf, 2015; Vieille Marchiset, 1998).

In the course of our study, we observed that an opponent's humiliation has also become a real stake, sometimes much more important than that which defines this team sport, namely, to score more points than the opposing team to win the game. Indeed, during some matches, one-onone duels get organized whose aim, for the defender as well as the player in attack, is to make a good impression. The analysis of this interaction ritual (Goffman, 1967) lends itself to our case study, insofar as the Cain-ris must abide by a certain outside constraint, to a "course of action," and must systematically risk losing face while trying to enhance it through their actions. The protagonists will thus have to defend their social face or maybe their Cain-ri face. In the course of these duels, the player, whether he be attacking or defending, will do his best to make life tough for his opponent and make him lose face in front of the other players. He will make him lose face more evidently if he can get the support of an audience (Sudre, 2015). To get what they want, with a lot of humor often or, according to Goffman (1967), by using jokes and farce, basketball players will per- form the most fanciful dribbles (passing the ball under the defending player's legs, putting it on his head without the defender being able to intercept it, or dancing with the ball to provoke his counterpart), achieve a poster dunk on an opponent, or even block his shot.

We should also emphasize that in a game situation, a player achieving a quick dribble and making his adversary fall will be cheered and even acclaimed. As in the United States, the audience and the teammates of the player who humiliates his rival will interact directly with this "ankle breaker" and hereby reinforce his social face (Goffman, 1967). In the course of a one-onone, if the player in defense falls following a dribble, meaning the speed of the player with the ball destabilizes him and he loses his footing, he finds himself in a disgraceful situation (Champigny diary entry excerpt). He literally loses face because he has not been able to meet the challenge and has been subjected to the worst indignity. The importance granted to the humiliation of an oppo- nent is also present in defensive phases. When a player manages to block the adversary he defends on, the audience will instantly react by shouting "Ouch," as if its members shared the pain of the humiliated offensive player (Champigny diary entry excerpt). The more violent the block, the more enthusiastic and expressive the audience is, showing empathy for the humiliated player and celebrating the player who performed the block.

As our field study shows, the development of hip-hop ball in France has thus deeply changed the Cain-ris' ways of playing. In the United States, individualistic logics have always pervaded the history of American basketball and, according to some observers, have even culminated in the emergence of the African American culture in American basketball (Colas, 2016; Kretchmar, 2008). Thus, tensions are visible in the way bas- ketball is played and considered in the United States. These tensions often translate in the collective sport unconscious 
into a so-called "collective white basketball uncon- scious" versus a more individualistic basketball associated with a Black unconscious (Colas, 2016, p. 67). Our study shows that in France, there are collective and more individualistic ways of playing. Nevertheless, it is important to both emphasize and recall what differentiates American basketball from French basketball. First of all, in its social and political context, the racial issue in France is not inherent to a formal distinction between team basketball (white basketball) and individualistic basketball (Black basketball). Race is not a determining factor in the way basketball is conceived, here. Then, if there is a game style opposition in France as in the United States - viewed here in its historical dimension - the difference crystallizes mainly around the transcultural dimension. Indeed, this cultural dimension has an important impact in France because antagonisms between coaches and Cain-ris are even more pronounced. Cain-ris are strongly influenced by the hip-hop ball culture and its values, which are, in fact, very American by definition (style, music, values, . . .). In other words, hip-hop ball culture in France has created a new relationship with basketball, which is reflected in an increasingly individualistic game in recent years.

\section{The Cain-ris as "Outsiders"}

Pretending that club basketball embodies the spirit of the collective game's foundation would surely be illusory. Nevertheless, we observed that coaches try to develop a kind of basketball based on team spirit and collective values (Colas, 2015). Indeed, trainers try to unite their players around a common game project through different means, such as physical and tactical exercises. The aim of these exercises is to develop teamwork, in addition to speeches with messages focusing on solidarity (Paris basketball camp diary entry excerpt). It seems that as "the agents of the modern basketball state, they seek to wrest from the players control over the technical, tactical, and stylistic devel- opment of the sport" (Colas, 2016, p. 50).

During the course of our study, we often saw endurance exercises in which players have to pass a test together (sequences of runs over long periods of time or even inter- val training). The coaches can also punish the whole team when one player makes a mistake and, for instance, ask them to do sets of push-ups. To develop a team spirit, they also often use the cat and mouse game to force the cat basketball players to catch the mice by opting for the passing game as a way to achieve their own ends, rather than dribbling. To reach this goal, the coaches build their pedagogical work around collec- tive game principles and orientations of their own design, hoping for their players to follow the teamplay tradition, that is, putting forward collective values, not individu- alistic ones.

Consequently, the style of play promoted by the coaches refers to an organized kind of basketball, labeled as "academic," which structures the players' moves and decision making (Adamkiewicz, 1998; Sudre \& Oboeuf, 2015; Vieille Marchiset, 1998). The coaches' game principles are based on clearly defined values: thinking of the team before thinking of oneself, insisting more on ball movement through the passing game between unmarked players; being efficient before putting on a show; looking for the open spots of the court, dribbling as little as 
possible; succeeding through simplicity; and defending without trying to achieve individual feats. These values form the cornerstone of the norms the coaches will try to impose upon their players. Our observation and interviews highlight the fact that the coaches do not care much for the athletic dimension and individualization process that hip-hop basketball emphasizes: "It [the hiphop ball way of playing] is based on the NBA, on physical factors, dunking, running fast. The NBA's image, which is very flashy, can be felt in French basketball. That's also a pity because when you talk with young players, they ask you what they could do to jump higher, to run faster. You'd rather tell them what they should do to score more field goals, to dribble better and make better passes. What's bothersome, at that level, is that we try to copy American culture and things we can't do". (Nicolas, a 36-year-old)

The Cain-ris' style of play, which we described previously, is often criticized by coaches because it encourages individual expression at the expense of the collective efficiency they seek: "We're headed for a lot more physical kind of basketball, played by athletes. That's achieved at the expense of the game, it takes precedence over the collective, there are a lot more individual actions which lead to a field goal than collective ones. I'm getting more and more fucking bored [sic] watching high-level basketball because it confines itself to one-on-ones or classic pick and rolls. I advocate collective action and that's what we try to do with young players, to have a welloiled team game and put everyone forward rather than having only one-on-ones. Unfortunately, that's what we see in the NBA. Young players take that as a model and tell themselves they are going to do the same thing. But no, it's the next step, first they have to learn the basics and improve physically". (Jean-Philippe, a 31-year-old)

Some moves that are favored by the Cain-ris, like dribbling, become an obsessive fear for the coaches because their excessive use could potentially harm the collective game. Gilles Vieille Marchiset explains that "team organizations [club play] (defen- sive or offensive playing systems, tactical drawings, etc.) appear as a constraint which impedes the freedom of action" (Vieille Marchiset, 1998, p. 208). The notion of free- dom, to which the Cain-ris are attached (Sudre \& Oboeuf, 2015), is challenged in institutional basketball insofar as the coaches "are tougher so that young players do not get it all wrong by doing what they see on TV" (Jean-Philippe, a 31-yearold).

Basketball coaches have this will to spread an organized, collective kind of basketball, which they deem efficient, a "benchmark basketball."

To a certain extent, there is a kind of cultural gap between the coaches and the Cain- ris, who are perceived as deviant players. The coaches take a dim view of the intrusion of this cultural practice hip-hop ball represents, which they consider inferior and not adapted to club basketball. Incidentally, we frequently heard coaches say that certain Cain-ri players cannot play for a club or that they will harm the team because they failed to integrate the institutional game culture (Khomutovaa, 2016).

According to the coaches, the Cain-ris transgress the rules imposed in club basket- ball and are labeled as "outsiders." On this matter, Howard Becker indicates that it is social groups 
that create deviant behavior "by making rules whose infraction creates deviance" (Becker, 1963). This is a result of a collective judgment based on a group's rules and essential values an individual may have transgressed: "The deviant is one to whom that label has successfully been-applied; deviant behavior is behavior that peo- ple so label" (Becker, 1963, p. 9). In our study, the coaches throw the blame on these outsiders to protect themselves from hip-hop ball's influence and preserve the institu- tional game so dear to them. The Cain-ris, whose practices are too different from those expected by the coaches, will be pigeonholed, stigmatized, and seen in a bad light by the coaches (Champigny diary entry excerpt). Actually, a player who dribbles too much, who does not play collectively, who grants too much importance to showman- ship rather than efficiency is seen as deviant. He does not respect club game values and those advocated by the coach and immediately finds himself in an awkward position with the person (the coach) guaranteeing the values of the social group (institutional basketball).

In the context of our study, the coaches seem to constitute the social group that is the more likely to impose and uphold a number of norms critical of the Cain-ris' behavior. In fact, the coaches' hierarchical status within the club gives them a socially superior position to that of the players. Their authority is stronger, relatively uncon- tested, and allows them to pass judgment against and then punish, when necessary, the deviant individual. Howard Becker underlines that the groups that are "best able to enforce their rules" are those "whose social position gives them weapons and power" (Becker, 1963). The imposition of norms is thus reserved to social groups that have a higher social status. Finally, the coaches are "moral entrepreneurs" (Becker, 1963) as they try to impose rules and norms to observe on the Cain-ris. They pursue the satis- faction of the interests of the institution they are responsible for (clubs, federation), design and enforce rules others - the Cain-ris - fall under: If they pursue the satisfaction of their own interests, they commit acts considered as deviant (Becker, 1963).

Once the players have been judged as deviant, the moral entrepreneurs will make this game value transgression audible to all within the basketball court. Very often, the coaches do not hesitate to raise their voices with these outsiders. On the sidelines, one can hear various ways to reprimand players: "It's not basketball, let go of your ball!"; "If you continue, I'll bench you!"; "Next time, you're out"; "This is not the NBA!"; or even "Hey Kobe, you think you're on your own on the court?" - a reference to former Los Angeles Lakers star Kobe Bryant, who was often perceived by French coaches as an individualistic player. By expressing their disapproval of these deviant players in this manner, the coaches also show the way for other players. Deviant players are chastised, so that other players internalize the rules of conduct to follow. As coach MarieThérèse says, "it's a blessing in disguise." During trainings or matches, these norms are repeated over and over again to gradually familiarize the players with them. Players internalize them, and they all know the meaning of norms at a given time and the risks incurred by transgressing them in certain situations. By blaming the outsider, coaches pass on to other players the rules they should not transgress. Acting like this allows the coaches to "bring the infraction to the attention of others; an infraction can- not be ignored once it is made public" (Becker, 1963).

Some coaches also use speeches at the end of games or training sessions to make deviant actions public and unite the players around their vision. They do not hesitate to gather the players 
to raise their awareness on the "proper" way to play basketball. In this way, the coaches stress the essential points that characterize the group's values "to play the right way" (Colas, 2016, p. 139). When we observed basketball camps the coaches often said: "If you want to win matches, you'll need to play as a team"; "You need to play together more! You don't help one another enough"; and so on. These sentences are meant to mobilize the players and make them become aware that the team values they spread are essential to becoming a seasoned basketball player. During these exchanges, the coaches do not hesitate drawing the other players' attention to the deviant players without, however, citing them. They lay blame, specify what is wrong in the way they play, explain what needs to be changed at all costs to win games. To achieve that, the coaches indulge in a subtle exercise: While observing deviant play- ers, but without staring at them too much or by speaking skillfully and blowing the whistle on them without calling them by their name, they make the whole team under- stand who the real "culprits" are (Paris basketball camp diary entry excerpt).

The players then know the rules of the game. If they transgress the "laws," they will be sanctioned. Henceforth, the players deemed as "outsiders" are reprimanded by the coaches with sanctions taking various forms: punishments in the shape of physical exercises-push-ups, crunches, "suicide drills" (suicide drills are endurance exercises in which players are mainly forced to sprint back-and-forth, for a period of time imposed by the coach)—verbal and public reprimands singling out the outsider or even "benching." For most players, this expression is associated to a feeling of social devaluation. The player who is benched by his coach "loses face" (Goffman, 1967). The deviant player feels worthless vis-à-vis the audience, his opponents, his team- mates, and his coach. His social face is damaged, he thus cannot put his best face for- ward (Goffman, 1967) any more. The basketball court (the place where the individual tries to show a positive social face of himself) is uncompromising: It gives players a chance to express their skills and put up a good show, but in return it can devalue them, jeopardize their reputation at any time. According to Goffman (1967), becoming aware that we can maintain face allows us to gain confidence, some assurance. Conversely, looking bad or looking foolish generates shameful feelings or even humiliation.

As we just noted, the coaches have a special place on the social ladder of club basketball. They consider themselves and are considered by most players as the guardians of traditional and institutional basketball. Given this status, they feel responsible for the evolution of the institutional practice of basketball. Their aim is to safeguard and spread their values. They thus fight for cultural stakes while trying to preserve the hierarchical positioning, within which they occupy a comfortable, advantageous place insofar as it grants them power, a status, and a meaningful role.

\section{Adapting in Order to Exist in Club Basketball}

Although relationships may be conflictual between Cain-ris and coaches, our study revealed some kind of negotiating game taking place between these two groups. It so happens 
coaches sometimes include "hip-hop balled" players in their team. They lean on these players often perceived as deviant to win games. They do so as they realize that the process of acculturation of the Cain-ris to the hip-hop ball culture has contrib- uted, in their view, to a major technical evolution in these young players: "Yeah, it has benefits [the hip-hop ball culture]. People are a lot stronger individually, in one-on-ones, they can drive their player more easily, they dribble better, they can score acrobatically. Before, guys dribbled like this [he mimes a perfectly straight, handball-like dribble]. Before, group performance gave you the edge whereas now, I think they are stronger individually, more skilled, so that's very positive but it shouldn't be at the expense of team play". (Nicolas, a 36-year-old)

In other words, hip-hop ball culture has individualized the game-running counter to the coaches' values-while enabling scores of young players to develop important abilities in their use of the ball (dexterity when dribbling above all) and in the way they play one-on-ones. These technical improvements have been acknowledged by coaches, who sometimes use the Cain-ris when their "hip-hop balled" basketball can improve their team's sports performance (Champigny diary entry excerpt). When it comes to play efficiently and improve the team's aggressive offensive play, for instance, coaches often call upon Cain-ris. The stake for them is thus to handle Cain-ris in a way that does not compromise the team strategy. As Nicolas underlines, "when you have a player who's very good individually, you have to know how to make good use of him."

As for Cain-ris, they like to play a more "hip-hop balled," a "freer" style of basket- ballas opposed to the coaches' more organized approach — and a more freestyle kind of game, that is, promoting its individual and spectacular nature: "I prefer freestyle, there is more freedom than when you play for a club. You're not as free when you're part of a club team, it's not necessarily the coaches' fault because they try to help us rise [the level of play], to make us improve. I think things are too strict in a club, players are starting to quit, it's becoming too serious. Whereas when you play street basketball, you can do whatever you want, you don't need a coach, people can see if you play well or not". (Gibhrel, a 16-year-old)

In interviews, Cain-ris cxpress their desire to play the way they like in clubs. It is important to note that for Cain-ris, streetball or the "street" is the most appropriate place for the expression of their hip-hop ball culture (Duret \& Augustini, 1993; Vieille Marchiset, 1998; Vieille Marchiset \& Vieille, 2006). Without coaches or strict rules as in institutional club basketball (Adamkiewicz, 1998; Bordes, 2000; Lefèvre, 1998), Cain-ris feel they are able to play more freely, as they see fit, reproducing all of the NBA and AND1 stars' moves: "There is a lot more dribbling in streetball, it's more spectacular. When I see streetball matches, I find that more spectacular. Since there are fewer rules, we can do more things. We can put the ball on the opponent's head, we can pull down the shorts, I do it from time to time". (Axel, a 15-year-old)

Although Cain-ris enjoy hip-hop ball culture and playing styles, they need to adjust to institutional basketball and, to some extent, comply with its rules to gain recogni- tion. They change hats depending on the situations they find themselves in. If they want to play for a club's 
team and ultimately be considered as club players by coaches, Cain-ris must set aside their passion for hip-hop ball, or at the very least, dampen it and teach themselves how to better adjust to the codes and values of institutional basket- ball promoted by their coaches.

We observed a great sense of flexibility among these young players, enabling them to adjust to their coaches' expectations. On several occasions, during the interviewing or observation phases, we noticed that these players often strived to match their repre- sentations of the game with their coaches' vision and speeches. Although they are fervent hip-hop ball enthusiasts and derive a lot of pleasure from playing it, Cain-ris also emphasize their respect for club basketball (Paris basketball camp diary entry excerpt). They overvalue club basketball practice, viewing club basketball culture more positively than hip-hop ball culture.

We call this the "paradox of the acculturated": Cain-ris are caught up in their pas- sion for hiphop ball, so much so that they copy game patterns used in American bas- ketball, but they also acknowledge institutional basketball as a benchmark practice. They have internalized the values and game styles of institutional baskeball while being appreciative of the basketball style influenced by American hip-hop ball: "Things are more structured in clubs. AND1 basketball or streetball, it's great to watch, I love it, but there's no goal, it's not organized, there's no team spirit, it's just great to watch. It's great to watch because without all of basketball's rules there's more freedom of movement, it becomes choreographies. It's stuff learned by heart, it's freestyle with basketballs, just to humiliate the player. If there wasn't more, I wouldn't like it, I couldn't appreciate this kind of basketball if I didn't know club basketball'. (Jordan, a 18-year-old)

In the end, some Cain-ris admit to liking a more organized kind of game, which, in their own words, is a "European" way of playing. Cain-ris thus find themselves in a paradoxical situation: they say they enjoy American hip-hop ball culture, but they also have to acknowledge the benefits of a more institutional basketball: "I prefer to play for a club, it's not every man for himself, we don't try only to do freestyle, acrobatics. In a club, we have to play as a team, it's more varied, you can try some street movements but you must leave it at that ... "(Gibhrel, a 16year-old). "For me, a good basketball player is a guy who can play collectively and make his teammates play. He must not just dribble, he must be an all-round player. He must know how to shoot but he must also make some good passes. He must have a vision of the game. It's no use if they keep the ball ... "(Lindsay, a 17-year-old)

In actual facts Cain-ris implicitly reinforce their coaches' approach to basketball. They consolidate their coaches' vision by devaluing, at times, the way they play bas- ketball and their passion for hip-hop ball: "I prefer club basketball because there are more playing, positioning systems, I don't like street because it's more about one-on-ones, I prefer to play for a club and there's a big difference. When you play street, there's no real system, you try to make your opponent fall, whereas in matches it's more serious, you have systems to comply with, a game, a collective". (Yannick, a 18-year-old) 
Ultimately, these young players have experienced various cultural universes consti- tutive of their basketball identity. Following Roger Bastide in his analysis of the "compartmentalization principle," Cain-ris are able to disconnect, to pass from one situation to the next and adapt without any particular effort, and live normally in apparently incompatible successive states (Bastide, 1955). The compartmentalization principle concerns individuals overcome by upheavals in identity and culture. In this situation, individuals must adapt their behavior to their references or original culture (Cuche, 1994). In our study, we noticed that Cainris' playing style is context dependent. They adapt their behaviors to the social constraints that weigh in on them.

In real life, the multiple personality syndrome of Cain-ris (Mead, 1934) falls into the Plural Actor category as defined by Bernard Lahire (2010). Although Cuche stresses the ability of actors in a pluricultural society to carve up their social world into watertight compartments to the point of being torn between various cultural universes (Cuche, 1994, p. 61), Bernard Lahire, on the contrary, believes that "in the face of each 'new' situation that presents itself, the actor will act by 'mobilizing' (without necessar- ily being aware of this mobilization) embodied schemes that the situation calls forth" (p. 66). Lahire (2010) also adds that the pertinence of these schemes "depends on the social contexts of their applications (social micro-situation or configuration, specific social world, field, etc.) . . . . The same actor learns to develop different schemes of action . . . in different social contexts: he is not necessarily the same person as a father, as an office worker with this colleagues . . , as a son, or as a member of a voluntary organization or religious community". (p. 81)

Due to their internalization of various social and cultural dispositions acquired through experience, Cain-ris act differently whether they play "street" or club basketball. Their "Americanness" expresses itself more in streetball than in a more institutional game situation, as in a club, under their coach supervision. Bernard Lahire explains that "each singular individual can be the bearer of a plurality of dispositions" which are in sleep mode or inhibited, but that may be triggered when needed (Lahire, 2010, p. xii).

\section{Conclusion}

The aim of this research was to measure the evolution of basketball practices in the Paris area by examining the influence of hip-hop ball culture on young players. In the course of our survey, we found out that the hip-hop ball culture has deeply changed these players' playing styles and also their understanding of this sport. The advent of Hip-hop ball has provided a new momentum to French basketball, especially, among Cain-ris. Their individual skills have improved to the extent that France has now "a generation of dribblers like we've probably never seen before," remarked Gérard Bosc (Gérard Bosc is a former FFBA National Technical Director and is regarded as one of the leading historians of French basketball today). Furthermore, the players' skills and dexterity with the ball have evolved considerably, but so has their 
understanding of basketball. Progressively, the game has become more individual, with interindividual duels during the games aiming to give players opportunities to showcase their talent and earn peer recognition. Our study also shows that the hip-hop ball culture has not been well received by club basketball coaches, who are representatives of the French basketball traditional and institutional game.

For coaches, and above all for those who fiercely defend the "institutional" and "European" game, this "hip-hop balled" style of basketball jeopardizes the collective practice of basketball taught in clubs. In other words, coaches aim to pass on their own representations of basketball to their players and protect them, at the same time, from the "American shadow" (Archambault et al., 2007). For coaches, the American shadow represents a metaphor for an exacerbated form of individualism "overshadowing" institutional basketball and running counter to their basketball culture. In fact, the conflict between coaches and Cain-ris centers on values. Coaches and Cain-ris are equally passionate about the sport, but they do not perceive it in the same way - each group aiming to play it as it sees fit. Because of their high-ranking position in the bas- ketball establishment, coaches find themselves in a dominant position over the Cain- ris. Cain-ris must comply with the institutional model imposed by coaches and integrate values and standards of play that are not their own. As coaches rely on French and European basketball institutional values, young Cain-ris need to adjust their play- ing style accordingly. If Cain-ris fail to play by the coaches' rules or adjust to their values and norms, they might feel excluded or marginalized within the team. As the hip-hop ball culture is less legitimized today (Bourdieu, 1979; Lahire, 2004) than the institutional basketball culture, Cain-ris may end up being deemed "deviant players" by the socially dominant group.

Ultimately, the cultural divide between hip-hop culture and institutional basketball culture goes beyond the integration issue of the young Cain-ris: It points out other identity issues in French basketball, requiring a more comprehensive perspective. Hip-hop ball pervasiveness in France, owing to the success of NBA stars and AND1 basketball, points the way toward a reexamination of basketball's identity while rais- ing new questions: What is French basketball today? What is its identity? As American basketball gains grounds in the French media, is there a generational gap in French basketball? In other words, are there two basketball cultures in France today: that of a young generation influenced by the American media and that of an even younger gen- eration clinging to the European model? Last but not least, is there a French basketball model and playing style specific to French players? Has French basketball been "territorialized," "regionalized," or "americanized"? 


\section{References}

Abercrombie, N., Hill, S., \& Turner, B. S. (2000). Participant observation. In Dictionary of sociology (4th ed., p. 256). New York, NY: The Penguin.

Adamkiewicz, E. (1998). Les performances sportives de rue [Street sports performances]. Les Annales de la recherche urbaine, 79, 50-58.

Andrews, D. (1999). Whither the NBA, whither America? Peace Review: A Journal of Social Justice, 11, 505-510.

Andrews, D. (2007). Basket-ball-ball, politique et culture de rue [Basketball, politics and street culture]. In F. Archambault, L. Artiaga, \& G. Bosc (Eds.), Double Jeu. Histoire du basket- ball entre France et Amériques [Double Game. History of basketball between France and the Americas], (pp. 229-246). Paris, France: Vuibert.

Appadurai, A. (1996). Modernity at large: Cultural dimensions of globalization. Minneapolis: University of Minnesota Press.

Archambault, F. (2012). La politique des bloc(k)s: Basket-ball ball et guerre froide [The poli- tics of the block(k)s: Basketball and Cold War]. Matériaux pour l'histoire de notre temps [Materials for the history of our time], 36, 33-39.

Archambault, F., \& Artiaga, L. (2007). Plus vite, plus haut, plus riche. La médiatisation de la culture sportive américaine au XXè siècle [Faster, higher, richer. Media coverage of American sports culture in the 20th century]. Le Temps des Médias [The Time of the Media], 8, 137-148.

Archambault, F., Artiaga, L., \& Bosc, G. (2007). Double Jeu. Histoire du basket-ball entre France et Amériques [Double Game. History of basketball between France and the Americas]. Paris, France: Vuibert.

Axthelm, P. (1970). The city game: Basketball from the garden to the playgrounds. Cutchogue, NY: Buccaneer Books.

Bastide, R. (1955). Le principe de coupure et le comportement afro-brésilien [The cutting principle and Afro-Brazilian behaviour]. Anais do XXXL Congresso Internacional de Americanistas, Sao Paulo (1954), Anhembi, Sao Paulo, 1, 493-503.

Becker, H. S. (1963). Outsiders: Studies in the sociology of deviance. New York, NY: Free Press. Bolotny, F. (2002). Basket-ball et télévision: une impossible histoire d'amour? [Basketball and television: an impossible love story?] In F. Archambault, L. Artiaga, \& P. Y. Frey (Eds.), L'Aventure des "grands" hommes. Études sur l'histoire du basket-ball [The Adventure of the "great" men. Studies on the history of basketball] (pp. 227-251). Limoges, France: Presses Universitaires de Limoges.

Bordes, P. (2000). Jeux de rue au-delà du bricolage ludique [Street games beyond playful crafts]. Vers l'Education nouvelle, 494, 20-23. 
Bourdieu, P. (1979). La Distinction. Critique sociale du jugement [Distinction: A Social Critique of the Judgement of Taste]. Paris, France: Les Éditions de Minuit.

Boyd, T. (2003). Young, Black, rich, and famous: The rise of the NBA, the hip hop invasion, and the transformation of American culture. New York, NY: Doubleday.

Colas, Y. (2015). Getting free: The arts and politics of basketball modernity. Journal of Sport and Social Issues, 39, 267-286.

Colas, Y. (2016). Ball don't lie! Myth, genealogy, and invention in the cultures of basketball. Philadelphia, PA: Temple University Press.

Cole, C. L., \& Andrews, D. L. (1996). "Look-It's NBA showtime!”: Visions of race in the popular imaginary. Cultural Studies, 1, 141-181.

Cuche, D. (1994). Le concept de "principe de coupure" et son évolution dans la pensée de Roger Bastide [The concept of the "cut-off principle" and its evolution in Roger Bastide's thinking]. In P. Laburthe-Tolra (Ed.), Roger Bastide ou le réjouissement de l'abîme [Roger Bastide or the rejoicing of the abyss] (pp. 69-83). Paris, France: L'Harmattan.

Cunningham, P. L. (2009). "Please don't fine me again!!!!!” Black athletic defiance in the NBA and NFL. Journal of Sport and Social Issues, 33, 39-58.

Descamps, Y., \& Vacheron, I. (2013). Où le ghetto (se) joue. Playground, basket-ball et cul- ture afro-américaine [Where the ghetto (is) playing. Playground, basketball and African- American culture]. Géographie et cultures [Geography and culture]. Retrieved from https:// gc.revues.org/3088

Duret, P., \& Augustini, M. (1993). Sports de rue et insertion sociale [Street sports and social integration]. Paris, France: National Institute of Sport, Expertise, and Performance.

Ferber, A. L. (2007). The construction of Black masculinity: White supremacy now and then. Journal of Sport and Social Issues, 31, 11-24.

Fortunato, J. A. (2000). Public relations strategies for creating mass media content: A case study of the National Basketball Association. Public Relations Review, 26, 481-497.

Frey, D. (2004). The last shot: City streets, basketball dreams. Boston, MA: Houghton Mifflin. Gilroy, P. (1993). The Black Atlantic: Modernity and double consciousness. Cambridge:

Harvard University Press. Giulianotti, R., \& Robertson, R. (2007). Globalization and sport. Oxford, UK: Wiley-Blackwell. Goffman, E. (1967). Interaction ritual: Essays on face-to-face behavior. Garden City, NY:

Anchor Books. Harter, H. (2007). Le basket-ball-ball et la culture sportive urbaine aux ÉtatsUnis: un regard

historique [Basketball and urban sports culture in the United States: a historical perspec- tive]. In F. Archambault, L. Artiaga, \& G. Bosc (Eds.), Double Jeu. Histoire du basket-ball- 
ball entre France et Amériques [Double Game. History of basketball between France and the Americas] (pp. 45-59). Paris, France: Vuibert. Hebdidge, D. (1979). Subculture. The meaning of style. Routledge: London \& New York. Khomutovaa, A. (2016). Basketball coaches' experience in working with multicultural teams:

Central and Northern European perspectives. Sport in Society: Cultures, Commerce, Media,

Politics, 19, 861-876. doi:10.1080/17430437.2015.1067777 Kretchmar, S. (2008). Basketball purists: Blind sentimentalists or insightful critics? In J. Walls

\& G. Bassham (Eds.), Basketball and philosophy (pp. 31-43). Lexington: University Press

of Kentucky. Lahire, B. (2004). La Culture des individus. Dissonances culturelles et distinction de soi $[$ The

Culture of individuals. Cultural Dissonances and Self-Distinction]. Paris, France: La

Découverte. Lahire, B. (2010). The plural actor. Cambridge, UK: Polity Press. Lakey, P. N. (2003). Acculturation: A review of the literature. Intercultural Communication

Studies, 12, 103-118. Lane, J. (2007). Under the boards: The cultural revolution in basketball. Lincoln: University

of Nebraska Press. Lapchick, R. E. (2008). 2006-07 racial and gender report card. Orlando, FL: Institute for

Diversity and Ethics in Sport, DeVos Sport Business Management Program. Retrieved from http://www.bus.ucf.edu/sport/cgibin/site/sitew.cgi?page=/ides/index.htx Lefèvre, B. (1998). Mythologie de la solidarité sportive [Mythology of sports solidarity]. Corps

et culture, 3. Retrieved from https://corpsetculture.revues.org/776 Leonard, D. J. (2006). The real color of money: Controlling Black bodies in the NBA. Journal

of Sport and Social Issues, 30, 158-179. Leonard, D. J. (2010). Jumping the gun: Sporting cultures and the criminalization of Black

masculinity. Journal of Sport and Social Issues, 34, 252-262. Lorenz, S. L., \& Murray, R. (2014). "Goodbye to the gangstas": The NBA dress code, Ray

Emery, and the policing of Blackness in basketball and hockey. Journal of Sport and Social

Issues, 38, 23-50. Martin-Breteau, N. (2011). Un "sport noir"? Le basket-ball et la communauté africaine-

américaine [A "black sport"? Basketball and the African-American community].

Transatlantica, 2. Retrieved from https://transatlantica.revues.org/5469 Mead, G. H. (1934). Mind, self, and society. Chicago, IL: The University of Chicago Press. Monier, B., \& Vivier, C. (2012). L'ère étatsunienne du basket français [The American era of 
French basketball]. Communication, 30. Retrieved from https://communication.revues.

org/3547 Ndiaye, P. (2008). La condition noire. Essai sur une minorité française [The Black Condition.

Essay on a French minority]. Paris, France: Gallimard. Palmer, C. (2004). Streetball: All the ballers, moves, slams, \& shine. New York, NY:

HarperCollins. Platt, J. (1983). The development of the "participant observation" method in sociology: Origin

myth and history. Journal of the History of the Behavioral Sciences, 19, 379-393. Rebillard, F. (2002). La presse basket-ball en France. Évolutions et diversifications des maga- zines consacrés au basket-ball [The basketball press in France. Evolutions and diversi- fication of basketball magazines] (1982-2002). In F. Archambault, L. Artiaga, \& P.-Y. Frey (Eds.), L'aventure des "grands" hommes. Etudes sur l'histoire du basket-ball [The adventure of the "great" men. Studies on the history of basketball] (pp. 205-225). Limoges,

France: Presses Universitaires de Limoges.

Riess, S. (1991). City games: The evolution of American urban society and the rise of sports. Urbana: University of Illinois Press.

Siblot, Y., Cartier, M., Coutant, I., Masclet, O., \& Renahy, N. (2015). Sociologie des classes populaires contemporaines [Sociology of the contemporary working classes]. Paris, France: Armand Colin.

Soulé, S. (2007). Observation participante ou participation observante? Usages et justifica-tions de la notion de participation observante en sciences sociales [Participant observation or observant participation? Uses and justifications of the notion of observant participation in the social sciences]. Recherches Qualitatives, 27, 127-140.

Sudre, D. (2012). L'identité Cain-ri ou comment se créer une identité culturelle à l'heure de la mondialisation? [The Cain-ri identity or how to create a cultural identity in the age of globalization?] Études Caribéennes, 22. Retrieved from http://etudescaribeennes.revues. org/5891?lang=en

Sudre, D. (2014). Etre “Cain-ri." L'appropriation du basket-ball américain en banli- eue parisienne [To be "Cain-ri." The appropriation of American basketball in the Paris suburbs]. Terrain, 62, 166-179.

Sudre, D. (2015). L'influence des “Mixtapes AND1" sur les jeunes basketteurs franciliens [The influence of the "Mixtapes AND1" on young basketball players in Ile-de-France]. In G. Ferréol \& S. Haissat (Eds.), Sports de rue et vidéo [Street sports and video] (pp. 43-59). Besançon: Université de Franche-Comté. 
Sudre, D., \& Oboeuf, A. (2015). Éléments de redéfinition du basket francilien au prisme du "hiphop ball" [Elements of redefinition of Ile-de-France basketball from the perspective of "hip-hop ball."] Society and Leisure, 38, 135-154.

Vieille Marchiset, G. (1998). Cultures et sociabilités des basket-balleurs de rue [Cultures and social skills of street basketball players]. In J.-F. Loudcher \& C. Vivier (Eds.), Le sport dans la ville [Sport in the city] (pp. 207-216). Paris, France: L'Harmattan.

Vieille Marchiset, G., \& Crétin, S. (2006). Les ambivalences des sports de rue dans les sociétés surmodernes. Une étude à partir du cas français [The ambivalences of street sports in overmodern societies. A study based on the French case]. Loisir et société, 29, 377-399.

Wieviorka, M. (2001). La Différence [The Difference]. Paris, France: Balland.

\section{Author Biographies}

David Sudre is a sociologist and an associate professor at the Université du Littoral Côte d'Opale. His work focuses mainly on sports, youth and urban cultures, but also on the processes of identification and racialization through a socio-anthropological approach. He is particularly fond of ethnographic investigation techniques.

Helene Joncheray is a sociologist and an associate professor at the University of Paris Descartes. The holder of a double PhD (University Paris Descartes - Sorbonne \& Macquarie University, Sydney), her first research work mainly focused on the socialization of athletes through inter and intracultural comparisons. The social construction of sports performance has been her main subject of study since her secondment at INSEP (French Institute of Sport).

Antoine Lech holds a PhD in sociology and teaches at Paris-Dauphine University. His research focuses on sports shows audiences. 